tion had convinced him that the creature drawn and photographed was an otter; the other pictures were of a motor-boat. He concluded by saying that his analysis of this problem showed that maybe the dictionary was right and a naturalist could be an unintelligent biologist.

The presidential address to the Zoological Section was given by R. M. Long, on "Butterflies and Moths of the Horsham Area". The address was illustrated by colour slides from the president's photographs, dealing mainly with the camouflage of many of the species in the area. He spoke of the success achieved with his mercury-vapour-lamp trap: as many as a thousand specimens were taken on a good night. $\mathrm{He}$ had recorded 31 species of butterfly and 347 of moth in his garden noar the Carfax at the town centre. $\mathrm{He}$ asked that, when particular trees and hedgerows were the habitat of the rarer species, the Council for Nature and the County Naturalist Trust be notified to cnable an order to be obtained for their preservation.

The Archæological Section was addressed by the president, G. P. Burstow, on "Recent Excavations in Sussex". He spoke of the excavations with which he had been associated, especially at Monkdown Court, near Findon, where three years work had revealed 900 post holes of an iron-age village occupied between 500 and 300 в.c. There was evidence of drying racks, storage pits and a quantity of pottery with hæmatite surface. The site was later occupied by the RomanoBritish, a shrine connected with the worship of the ox had been uncovered, a possible association with a local Celtic god. Vast quantities of Roman pottery had been recovered, and many bronze objects, notably a plaque of a charging boar. Mr. Burstow described other excavations at Ranscomb Hill near Mount Caburn and Balcombe quarry. It was in middle Sussex where research work was most needed, a mistaken idea that it was unoccupied in ancient times being due to insufficient archæologists having been interested in the area.

The president of the Botanical Section, D. McClintock, chose as the title of his address "Alien Plants in South-east England". He spoke of the recent introductions and of the probable manner in which they arrived. Most were introduced by man, many from the Mediterranean area, then distributed by animals, being carried from place to place in their wool or fur. The bomb craters of the War were favourite sites, providing a large number of species. Buddleia was an outstanding example, being introduced from China as a rather rare plant in 1887; it was widely distributed in the countryside by 1926 .

Dr. R. Thurrell, as president of the Geological Section, gave an address on "Aspects of the Geology of the Horsham District". His talk was introductory to the excursion he was conducting during the congress. After mentioning that the area was now being examined in detail by the Geological Survey, he outlined the history of its investigation from early times. The Romans used Horsham Stone together with hardened clay as the foundation of the Stane Street at Slinfold. Iron was obtained from the ironstone in the Hastings Beds up to 1550; later limonite, from the base of the Wadhurst Clay and from the Weald Clay underlying the Horsham Beds, was the basis of the iron industry.

Mantell could be regarded as the pioneer of the systematic study of Wealden geology, his discovery of the remains of giant reptiles attracting interest as well as adding considerably to the knowledge of the conditions prevailing at the time of the deposition of the beds. The main uses of the Horsham Stone have been for roofing tiles, flag-stones and walls for farm buildings. Dr. Thurrell concluded by describing the method of capture of minor streams by the River Arun when, on surface examination, there would appear to be more likely directions for their flow.

Miss Joyce Pope addressed the delegates on the upbringing of young animals by human beings. Most people liked watching the development of young animals whether they be white mice or gorillas. At the onset Miss Pope said she wished to emphasize that both young birds and mammals are around alone before they had finished with parental care and it was a mistake to take them and attempt hand-rearing, for the parents were often close by and would be tending them. The exception was with those which had been abandoned or injured, often wished on you by friends. Even then the difficulty of the task should be realized and, where recovery seemed hopeless, it would be kinder to dispatch them painlessly. Voles were very good pets and when they were in the suckling stage she had found it better to feed with a small paint brush rather than with a fountain pen filler. Friendship with a hand-reared animal was apt to end with the animal 'becoming itself', becoming nervous and bad tempered, so one had to prepare it to fend for itself before liberating it in its native habitat. Miss Pope then showed the film "Elsa, the Lioness" to illustrate some of the points of her address.

Weather conditions, although troublesome, permitted the full excursion programme to be carried out. The botanists were conducted by 0 . Buckle on the chalk downs surrounding Chanctonbury Ring, the zoologists visited the secluded parts of St. Leonards Forest, under R. M. Long's guidance, to study the effects of reafforestation on wild life and to examine the working of the charcoal industry. The geological party, numbering seventy, visited the more important outcrops and exposures of the Wealden Series in the Horsham district under the direction of Dr. R. Thurrell.

The excellent arrangements for the congress were undertaken by the Horsham Natural History Society, for whom Mrs. R. Hurst acted as honorary secretary. F. J. EPPS

\title{
TARONG PYGMIES IN NORTH BURMA
}

$\mathrm{D}^{\mathrm{c}}$ URING March-April 1962 a team from the Burma Medical Research Society carried out an expedition to the Arumdum area $\left(97^{\circ} 40^{\prime}-97^{\circ} 45^{\prime} \mathrm{E}\right.$., $28^{\circ} 5^{\prime}-28^{\circ} 10^{\prime}$ N.) in the Adung Long Valley in the northernmost part of Burma. The primary object of the expedition was to study the recently discovered Tarongs - a pygmy tribe living in that area.
The team was led by Prof. M. Mya-Tu of the Department of Physiology, University of Rangoon, other members being Dr. Ko Ko, Dr. Aung Than Batu and Dr. Kywe Thein of the Directorate of Health, Burma, and Dr. C. J. R. Francis and U Than Tun Aung Hlaing of Prof. Mya-Tu's Department. 
The expedition Ieft Rangoon for Putao (Fort Hertz), some 800 miles north, in a Burma Air Force plane. From Putao it travelled 60 miles by car until the road ended. From there on, it proceeded on foot over mountain, river gorge and valley for nine days until Arumdum was reached.

The whole population of Tarongs (69) in that region was examinod. The team spent seven days in the area during which time it collected anthropometric, hæmatological and other physiological data, and also conducted dietary, goitre and intestinal parasite surveys. It also obtained information regarding the customs and beliefs of the Tarongs.

Detailed analyses of the results obtained are still in progress, but some proliminary conclusions may be drawn. Anthropologically, the Tarongs are of Mongolian stock, and are believed to be ethnologically closest to the Rawangs, a tribe of the Kachins. The majority of them are between 4-5 ft. in height, very fow being taller than $5 \mathrm{ft}$.

The Tarong blood groups show a high predominance of group B with group $O$ coming next. No person belonging to group A was found. Only two were of group AB. Group $\mathrm{M}$ was twice as common as MN. $\mathrm{N}$ was rare. Of the $\mathrm{Rh}$ group, CDo was most common. CDE was also fairly common.

Electrophoresis of hæmoglobin solutions, alkaline denaturation test for hxmoglobin $\mathrm{F}$, sickling and osmotic resistance tests were also performed. No hæmoglobinopathies were found.

Vital registration records are non-existent, but judging from the family-histories, there is a high infant mortality; but once the difficult childhood years are survived, the Tarongs seem to enjoy reasonably good health. There is little evidence of gross malnutrition, and they seem to be rolatively freo from serious infections like smallpox and plague. Intestinal diseases such as dysentery and worm infections also appear to be uncommon. As is to bet expocted in most hill tribes, a high incidence of goitre was evident and, side by side with it. cretinism.

The team also brought back samples of blood, stool and urine from the Tarongs for further examination, and also collected insects, arrow poisons and medicinal plants from the region for examination in Rangoon.

The report of the expedition will be published in the Proceedings of the Burma Medical Researct Society.
M. Mya-Tu
$\mathrm{U}$ Ko Ko
Aung Than Batu
U KYWE THEIN
C. J. R. Francis
Than Tun aung Huanc:

\section{AN ELEMENTARY INTERPRETATION OF SCIENCE}

$I^{\mathrm{N}}$ N January 1961, Purnell and Sons, Ltd., printed the first copy of Knowledge, a weekly colour journal edited by John Chancellor and an advisory board of Lady Violet Bonham Carter, Prof. C. N. L. Brooke, Mr. Norman Fisher, Mr. Walter Hamilton, Mr. John Sparrow, Dr. Dudley Stamp and Sir George Thomson. The success of this magazine in the field of goneral education has apparently encouraged the publication of a vory similar but more specialized magazine entitled Understanding Science*, under the senior editorship of Leslio Basford, with a consulting editorial board comprising Sir James Chadwick, Mr. Norman Fisher, Sir Harry Molville and Prof. J. Z. Young.

According to the chicf oditor it is "a new weekly magazine intended both for the general public and to help in doveloping the teaching of Science in schools". The general plan is that each issue will contain a selection of articles, each of which is a member of a series of articles outlining a particular branch of science. The first issue, for example, contains articles on biology ("Living Cells"), chemistry ("Atomic Structure of Flements"), electricity ("An Electric Circuit"), heat ("The Fireless Locomotive"), hydrostatics ("Floating and Sinking"), magnotism ("The 'Loves' and 'Hates' of Magnets") and technology ("Using a Micrometer"), as well as an article on Sir Isaac Newton. The cover design and articlo printed on the front and back constitute a special feature on topics of genoral scientific interest: the first of these is entitlod "Water and Life on Earth". Every twelfth issue will contain an index and title-page to facilitate collecting and binding of the copios: this habit will

* Understanding science, No. 1. (A New Colour Magazine which becomes an fincyclopedia.) Pp. io. Subscription rates: 52 weekly

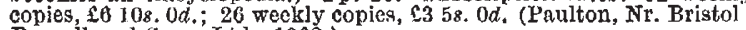
Purnell and Sons Ltd., 1962.) be further encouraged by the offer of special volume bindors both for the main articles and for the special features.

The text is very clearly printed, and on the whole tho largo diagrams and illustrations are good. The sections on the micrometer (issue No. 1, pp. 8-9), the? chemical balance (No. 2, pp. 24-25) and the microscope (No. 3, pp. 42-43) which would, as Mr. Basford suggests, provide science teachers with material for visual aids, are quite impressive. On the other hand, some of the biological drawings such as the worm, flowering plant and Spirogyra (No. 1, pp. 10-11, and the plankton (No. 4, pp. 56-57) are rather poor. Some of the material and illustrations are taken directly from the Junior Science Encyclopaedia (Sampson Low, Marston and Co., Ltd.). The topics are always treated as clearly and as simply as possible. Occasionally, therefore, they suffer the inevitable consequences of oversimplification and contain somewhat misleading statements such as: "Atoms are the smallest possible pieces of the basic pure materials that make the universe" (No. 1, p. 5) and "At another certain temperature water turns into a gas-steam. On the centigrade scale of temperature tho point at which this happens is defined as $100^{\circ}$ " (No. 1, back cover).

The editor claims that the magazine will present. science in a way which is easy to understand. He also claims that it will cover the equivalent of the Ordinary Level syllabus of General Cortificate of Education in chemistry, physics, biology, etc. Unfortunately, ho does not indicate how many years this will take. Nevertheless, the parents of young aspiring scientists may, perhaps, still consider 2s. every Monday a worth-while investment.

Michael C. Cox 